\title{
von Willebrand factor stimulates thrombin-induced exposure of procoagulant phospholipids on the surface of fibrin-adherent platelets
}

Citation for published version (APA):

Briedé, J. J., Wielders, S. J. H., Heemskerk, J. W. M., Baruch, D., Hemker, H. C., \& Lindhout, T. (2003). von Willebrand factor stimulates thrombin-induced exposure of procoagulant phospholipids on the surface of fibrin-adherent platelets. Thrombosis and Haemostasis, 1(3), 559-565. https://doi.org/10.1046/j.15387836.2003.00077.x

Document status and date:

Published: 01/01/2003

DOI:

10.1046/j.1538-7836.2003.00077.x

Document Version:

Publisher's PDF, also known as Version of record

Please check the document version of this publication:

- A submitted manuscript is the version of the article upon submission and before peer-review. There can be important differences between the submitted version and the official published version of record.

People interested in the research are advised to contact the author for the final version of the publication, or visit the DOI to the publisher's website.

- The final author version and the galley proof are versions of the publication after peer review.

- The final published version features the final layout of the paper including the volume, issue and page numbers.

Link to publication

\footnotetext{
General rights rights.

- You may freely distribute the URL identifying the publication in the public portal. please follow below link for the End User Agreement:

www.umlib.nl/taverne-license

Take down policy

If you believe that this document breaches copyright please contact us at:

repository@maastrichtuniversity.nl

providing details and we will investigate your claim.
}

Copyright and moral rights for the publications made accessible in the public portal are retained by the authors and/or other copyright owners and it is a condition of accessing publications that users recognise and abide by the legal requirements associated with these

- Users may download and print one copy of any publication from the public portal for the purpose of private study or research.

- You may not further distribute the material or use it for any profit-making activity or commercial gain

If the publication is distributed under the terms of Article 25fa of the Dutch Copyright Act, indicated by the "Taverne" license above, 


\title{
von Willebrand factor stimulates thrombin-induced exposure of procoagulant phospholipids on the surface of fibrin-adherent platelets
}

\author{
J. J. BRIEDÉ, ${ }^{*}$ S. J. H. WIELDERS, ${ }^{*}$ J. W. M. HEEMSKERK, ${ }^{*}$ D. BARUCH, ${ }^{\dagger} H$. C. HEMKER ${ }^{*}$ and T. LINDHOUT ${ }^{*}$ \\ *Department of Biochemistry, Cardiovascular Research Institute Maastricht, Maastricht University, Maastricht, the Netherlands; and †INSERM \\ U143, Le Kremlin-Bicêtre, France
}

\begin{abstract}
Summary. Studies from our laboratory have demonstrated that von Willebrand factor (VWF) stimulates thrombin generation in platelet-rich plasma. The precise role of VWF and fibrin in this reaction, however, remained to be clarified. In the present study we utilized thrombin-free planar fibrin layers and washed platelets to examine the relationship between platelet-fibrin interaction and exposure of coagulation-stimulating phosphatidylserine (PS) under conditions of low and high shear stress. Our study confirms that platelet adhesion to fibrin at a shear rate of $1000 \mathrm{~s}^{-1}$ requires fibrin-bound VWF. The cytosolic calcium concentration $\left(\left[\mathrm{Ca}^{2+}\right]_{\mathrm{i}}\right.$ ) of stationary platelets was not elevated and PS exposing platelets were virtually absent $(2 \pm 2 \%)$. However, thrombin activation resulted in a marked increase in the number of PS exposing platelets (up to $85 \pm 14 \%$ ) along with a transient elevation in $\left[\mathrm{Ca}^{2+}\right]_{\mathrm{i}}$ from $0.05 \mu \mathrm{mol} \mathrm{L} \mathrm{L}^{-1}$ up to $1.1 \pm$ $0.2 \mu \mathrm{mol} \mathrm{L}{ }^{-1}$. Platelet adhesion to fibrin at a shear rate of $50 \mathrm{~s}^{-1}$ is mediated by thrombin but not by fibrin-bound VWF. The $\left[\mathrm{Ca}^{2+}\right]_{\mathrm{i}}$ of these thrombin-activated platelets was elevated $\left(0.2 \pm 0.1 \mu \mathrm{mol} \mathrm{L}{ }^{-1}\right)$, but only a minority of the platelets $(11 \pm 8 \%)$ exposed PS. The essential role of VWF in this thrombin-induced procoagulant response became apparent from low shear rate perfusion studies over fibrin that was incubated with VWF and botrocetin. After treatment with thrombin, the majority of the adherent platelets $(57 \pm 23 \%)$ exposed PS and had peak values of $\left[\mathrm{Ca}^{2+}\right]_{\mathrm{i}}$ of about $0.6 \mu \mathrm{mol} \mathrm{L}^{-1}$. Taken together, these results demonstrate that thrombin-induced exposure of PS and high calcium response on fibrin-adherent platelets depends on shear- or botrocetin-induced VWF-platelet interaction.
\end{abstract}

Keywords: fibrin, platelet procoagulant activity, von Willebrand factor.

\footnotetext{
Correspondence: Dr T. Lindhout, Department of Biochemistry, Maastricht University, PO Box 616, 6200 MD Maastricht, the Netherlands.

Tel.: +31433881674; fax: +31433884159; e-mail: t.lindhout@bioch. unimaas.nl
}

Received 14 June 2002, resubmitted 26 September 2002, accepted 26 September 2002
Thrombus formation at an injured vessel wall involves platelet adhesion, platelet activation and fibrin formation. Previous studies have provided evidence that fibrin, besides physically entrapping platelets [1], may also be involved in signal pathways that result in the exposure of anionic phospholipids (PS) at the plasma membrane of platelets $[2,3]$. The presence of PS in the outer leaflet of the platelet plasma membrane is of physiological importance because of its critical role in maintaining thrombin generation at the surface of a developing thrombus [4].

Platelets adhere to fibrin by molecular mechanisms that vary with the surface shear rate [5,6]. At low shear rates, platelet adhesion is mediated by integrin $\alpha_{\mathrm{IIb}} \beta_{3}$ whereas at high shear rates an interaction between platelet glycoprotein (GP) Ib and fibrin-bound von Willebrand factor (VWF) tethers the platelets as a prerequisite for an irreversible, integrin $\alpha_{\mathrm{IIb}} \beta_{3}$-mediated, adhesion to fibrin [7-10].

Recently, conflicting reports appeared on the role for GPIb in the development of procoagulant platelets. Studies in plateletrich plasma revealed that VWF supports thrombin generation by two mechanisms: one that involves integrin $\alpha_{\text {IIb }} \beta_{3}$ but not fibrin and another one that depends on both fibrin and GPIb [3]. Other investigators studied the thrombin-dependent expression of procoagulant activity in suspensions of gel-filtered platelets and found that the GPIb binding site for thrombin, but not that for VWF, has a key role in the exposure of procoagulant phospholipids on the platelet surface, implying that VWF does not function in this response [11]. Earlier studies, however, indicated that PAR1 is the primary mediator of thrombin-stimulated platelet procoagulant activity, implicating that GPIb does not play a major role [12]. Thus, it remains to be clarified what role GPIb and the interaction with its physiological ligand VWF plays in the exposure of procoagulant PS.

In this study, we examined the stimulatory effect of fibrinbound VWF on the procoagulant response of fibrin-adherent platelets under flow conditions, utilizing a plasma free system to avoid any contribution of in situ generated thrombin. The procoagulant response was probed by the binding of annexin $\mathrm{V}$ in addition to changes in the cytosolic calcium concentration of adherent platelets. The data confirms that stable adhesion to fibrin requires VWF at high but not at low shear rate. This interaction does not result in increased cytosolic calcium levels, or in the exposure of PS. However, GPIb-VWF-mediated 
adhesion of platelets to fibrin appears to be a prerequisite for thrombin to induce PS exposure in association with transiently increased cytosolic calcium levels.

\section{Materials and methods}

\section{Materials}

Unfractionated heparin and bovine serum albumin (Sigma, St. Louis, USA); chromogenic substrate for thrombin, S2238 (Chromogenix, Mölndal, Sweden); D-Phe-Pro-Arg chloromethylketone (Calbiochem, San Diego, USA); 1,2-dioleoyl$s n$-glycero-3-phosphocholine (DOPC) and 1,2-dioleoyl-sn-glycero-3-phosphoserine (DOPS) (Avanti Polar Lipids, Alabaster, AL, USA); calcein acetoxymethyl ester and fura-2 acetoxy methyl ester (Molecular Probes, Leiden, the Netherlands) and botrocetin (Kordia, Leiden, the Netherlands) were purchased from commercial sources as indicated.

\section{Proteins and antibodies}

Recombinant human tissue factor was a kind gift of Dr Y. Nemerson (Mount Sinai School of Medicine, New York, NY, USA) and was relipidated as described before [13]. Human $\alpha$ thrombin was prepared as previously described [14]. An affinity purified polyclonal rabbit antihuman VWF antibody was obtained from the Central Laboratory of the Red Cross (Amsterdam, the Netherlands). Monovalent Fab fragments of a monoclonal antibody directed against GP Ib (6B4 Fab) described previously [15] were a kind gift of Dr H. Deckmyn (Laboratory for Thrombosis Research, Kortrijk, Belgium). Fluorescein isothiocyanate (FITC) labeled swine antirabbit IgG was from Dako A/S (Glostrup, Denmark). Purified VWF and a monoclonal antibody (MoAb 9) directed against the platelet $\alpha_{\text {IIb }} \beta_{3}$ binding site on VWF were described before [16]. Oregon Green 488labeled annexin V came from Nexins Research (Hoeven, the Netherlands). The source of the platelet $\alpha_{\mathrm{IIb}} \beta_{3}$ receptor blocker abciximab was as described [17]. The specific protease-activated receptor 1 (PAR1) ligand SFLLRN was obtained from Bachem (Bubendorf, Switzerland).

\section{Platelets}

Suspensions of washed platelets were prepared as described previously [18]. The supernatant of the final wash-step contained less than $3 \mathrm{ng} \mathrm{mL}^{-1}$ VWF. Where indicated, platelet-rich plasma was incubated with $2.5 \mu \mathrm{mol} \mathrm{L}{ }^{-1}$ calcein acetoxymethyl ester or $3 \mu \mathrm{mol} \mathrm{L}^{-1}$ fura- 2 acetoxymethyl ester in the presence of $0.1 \mathrm{U} \mathrm{mL}^{-1}$ apyrase during $45 \mathrm{~min}$ at $37^{\circ} \mathrm{C}$. The platelets were then spun down and washed twice with Hepes buffer pH 6.6 (in mmol L ${ }^{-1}$ : 10 Hepes, $136 \mathrm{NaCl}, 5$ glucose, $2.7 \mathrm{KCl}$, $2 \mathrm{MgCl}_{2}$, and $1 \mathrm{mg} \mathrm{mL}^{-1}$ bovine serum albumin) containing apyrase $\left(0.1 \mathrm{U} \mathrm{mL}^{-1}\right)$. Finally, the platelets were resuspended in Hepes buffer adjusted to $\mathrm{pH}$ 7.4. Platelets were counted (Coulter, Miami, FL, USA) and the suspensions were adjusted to $3.0 \times 10^{8}$ platelets $\mathrm{mL}^{-1}$.

\section{Preparation of planar fibrin layers}

Fibrin layer was prepared as originally described by Remijn et al. [19]. A parallel plate flow chamber was filled with $0.3 \mathrm{nmol} \mathrm{L}^{-1}$ tissue factor embedded in $30 \mu \mathrm{mol} \mathrm{L}^{-1}$ DOPS ( $25 \mathrm{~mol} \%) / D O P C ~(75 \mathrm{~mol} \%)$ vesicles and incubated for $20 \mathrm{~min}$. Non-bound vesicles were removed by flushing the chamber with Tris-buffer ( $50 \mathrm{mmol} \mathrm{L}^{-1}$ Tris, $175 \mathrm{mmol} \mathrm{L}^{-1} \mathrm{NaCl}$, pH 7.9). Subsequently, the flow chamber was perfused (shear rate of $20 \mathrm{~s}^{-1}$ ) with plasma that was diluted 5-fold with Tris-buffer containing $1 \mathrm{UmL}^{-1}$ heparin and $3 \mathrm{mmol} \mathrm{L}^{-1} \mathrm{CaCl}_{2}$. After $20 \mathrm{~min}$, when a network of fibrin strands was formed, the flow chamber was flushed with Tris-buffer to remove plasma proteins. Immuno-staining with primary polyclonal rabbit antihuman VWF antibody ( $10 \mu \mathrm{g} / \mathrm{mL})$ during $60 \mathrm{~min}$ and a secondary FITC-labeled swine antirabbit antibody (1:50 dilution) during 60 min revealed the presence of VWF. The fibrin layer was then incubated for $1 \mathrm{~h}$ with $50 \mu \mathrm{mol} \mathrm{L}{ }^{-1}$ D-Phe-Pro-Arg chloromethylketone (PPACK) and with purified plasma-derived human VWF $\left(10 \mu \mathrm{g} \mathrm{mL}^{-1}\right)$. Finally, the flow chamber was rinsed with Hepes buffer during $10 \mathrm{~min}$ at a shear rate of $1000 \mathrm{~s}^{-1}$. Immuno-staining for VWF as described resulted in twofold increase in fluorescence intensity.

\section{Platelet flow studies}

The flow chamber used in this study was as described previously [20]. Perfusion experiments with washed platelets $\left(3.0 \times 10^{8}\right.$ platelets $\mathrm{mL}^{-1}$ ) in Hepes buffer containing $3 \mathrm{mmol} \mathrm{L}^{-1} \mathrm{CaCl}_{2}$ were performed at $100 \mu \mathrm{L} \mathrm{min}^{-1}$ in flow chambers with a slit depth of $200 \mu \mathrm{m}$ (shear rate $50 \mathrm{~s}^{-1}$ ) and at $125 \mu \mathrm{L} \mathrm{min}^{-1}$ in flow chambers with a slit depth of $50 \mu \mathrm{m}$ (shear rate $1000 \mathrm{~s}^{-1}$ ). All procedures were performed at ambient temperature $\left(21-22^{\circ} \mathrm{C}\right)$.

\section{Perfusion with thrombin-activated platelets}

The inlet of the flow chamber was connected to two syringes; one containing the platelet suspension $\left(3.8 \times 10^{8}\right.$ platelets $\mathrm{mL}^{-1}$ in Hepes buffer containing $3 \mathrm{mmol} \mathrm{L}^{-1} \mathrm{CaCl}_{2}$ ) and the other containing $0.5 \mu \mathrm{mol} \mathrm{L}{ }^{-1}$ thrombin in Hepes buffer. The pump-driven syringes were set at flow rates of 80 and $20 \mu \mathrm{L} \mathrm{min}^{-1}$, respectively, resulting in the perfusion of platelets that were activated with $100 \mathrm{nmol} \mathrm{L}^{-1}$ thrombin, just before they entered the flow chamber.

\section{Phase contrast and fluorescence microscopy}

Phase contrast and fluorescent real-time images were recorded as described before [18]. Briefly, the flow chamber was placed on the stage of an inverted microscope (Diaphot 200, Nikon, Tokyo, Japan). Phase contrast and fluorescence images are recorded via a $40 \times$ quartz oil-immersion objective coupled to a high-resolution and a low-light level intensified, chargecoupled device camera, respectively. Oregon Green 488, calcein and FITC fluorescence were observed with a 485-nm excitation filter (bandpass of $40 \mathrm{~nm}$ ), a 505-nm dichroic long-pass filter, 
and a 530-nm emission filter (bandpass of $30 \mathrm{~nm}$ ). Four fluorescence images were taken every $10 \mathrm{~s}$, digitized and averaged after subtraction of background images, and the resulting images were stored. Image analysis was performed off-line using Quanticell 700/900 software (Visitech, Sunderland, UK). Fura-2 fluorescence, as a probe for intracellular calcium concentration, was measured with alternating $340 \mathrm{~nm}$ and $380 \mathrm{~nm}$ excitation filters (bandpass $15 \mathrm{~nm}$ ), a 400-nm dichroic mirror and a $510-\mathrm{nm}$ emission filter (bandpass $40 \mathrm{~nm}$ ). Four fluorescence images were taken every $3 \mathrm{~s}$, averaged, background subtracted and ratio images were calculated. Calibration of fluorescence ratio to molar concentrations of intracellular calcium was according to Grynkiewicz et al. [21].

Platelet adhesion is expressed as the percentage of total area covered with fluorescent (calcein-loaded) stationary platelets, and was calculated from at least five different microscopic fields in three independent experiments. PS exposure is expressed as the percentage of total area covered with platelets that bind Oregon Green-labeled annexin V, and was calculated from at least five different microscopic fields in three independent experiments.

\section{Statistics}

To determine the significance of differences, $P$-values were obtained with a non-parametric test for two independent variables (Mann-Whitney test).

\section{Results and discussion}

\section{Shear-induced adhesion of platelets to fibrin and exposure of anionic phospholipids}

A thin fibrin layer was formed under flow from tissue factordriven coagulating human plasma at the glass coverslip surface mounted in a parallel plate flow chamber as described in Materials and methods. Scanning electron microscopy showed an homogeneous coverage of the coverslip area with fibrin strands varying in thickness from 0.1 to $0.3 \mu \mathrm{m}$ and aligned in the direction of the flow. No binding of Oregon Green-labeled annexin $\mathrm{V}$ to the phospholipids layer underneath the fibrin layer could be detected, suggesting a complete coverage of the glass surface with fibrin. In all perfusion experiments fibrin layers were used that were incubated with PPACK and VWF to inactivate fibrin-bound thrombin and to saturate the fibrin with VWF, respectively.

Perfusion of washed platelets at a wall shear rate of $1000 \mathrm{~s}^{-1}$ over the VWF-fibrin layer resulted in a rapid surface coverage with stationary (irreversibly bound) platelets (Fig. 1). After 10 min perfusion, the surface coverage was $75 \pm 7 \%$ (mean $\pm \mathrm{SD} ; n=15)$. This is slightly less than in similar perfusion experiments with PPACK anticoagulated whole blood (data not shown). Adhesion of stationary platelets appeared to depend on the interactions between VWF and the platelet receptors GPIb and integrin $\alpha_{\mathrm{IIb}} \beta_{3}$ for the following reasons: less than $1 \%$ of the surface was covered after $10 \mathrm{~min}$ perfusion with stationary

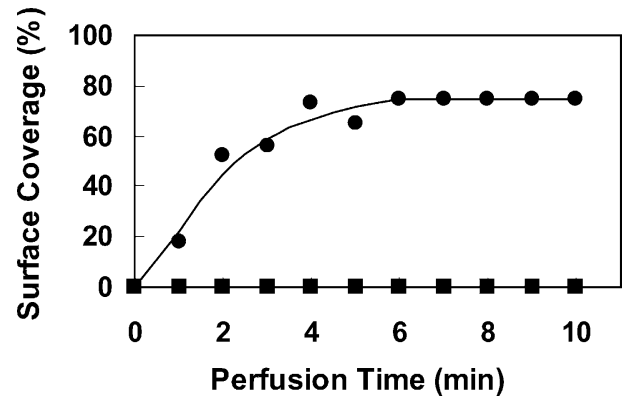

Fig. 1. VWF-mediated platelet adhesion on fibrin. Calcein-loaded washed platelets $\left(3.0 \times 10^{8}\right.$ cells $\left.\mathrm{mL}^{-1}\right)$ resuspended in Hepes buffer $\mathrm{pH} 7.4$ (in mmol L ${ }^{-1:} 10$ Hepes, $136 \mathrm{NaCl}, 5$ glucose, $2.7 \mathrm{KCl}, 2 \mathrm{MgCl}_{2}, 3 \mathrm{CaCl}_{2}$, and $1 \mathrm{mg} \mathrm{mL}^{-1}$ bovine serum albumin) were perfused at a wall shear rate of $1000 \mathrm{~s}^{-1}$ over a fibrin layer that was incubated with human VWF $\left(10 \mu \mathrm{g} \mathrm{mL}^{-1}\right)$ and PPACK $\left(50 \mu \mathrm{mol} \mathrm{L}^{-1}\right)$. Fluorescence images were captured at different time intervals and off-line analyzed for surface coverage. Symbols indicate: (O), control and ( $\mathbf{0})$, VWF-fibrin incubated for $1 \mathrm{~h}$ with polyclonal antihuman VWF antibody $\left(10 \mu \mathrm{g} \mathrm{mL}^{-1}\right)$ prior to perfusion with platelet suspension.

platelets when the fibrin layer was pretreated with [1] a polyclonal antihuman VWF antibody $\left(10 \mu \mathrm{g} \mathrm{mL}^{-1}\right)$ or [2] a blocking antibody $\left(20 \mu \mathrm{g} \mathrm{mL}^{-1}\right)$ against the integrin $\alpha_{\mathrm{IIb}} \beta_{3}$ binding site on VWF (MoAb 9). Moreover, essentially no platelets adhered when the platelets were incubated prior to perfusion with [1] Fab fragments of MoAb 6B4 $\left(10 \mu \mathrm{g} \mathrm{mL}^{-1}\right)$ directed against the VWF binding site on GP Ib or [2] abciximab $\left(20 \mu \mathrm{g} \mathrm{mL}^{-1}\right)$ an integrin $\alpha_{\mathrm{II}} \beta_{3}$ antagonist. Taken together, these findings are compatible with the notion that VWF must sequentially engage both GPIb $\alpha$ and $\alpha_{\mathrm{IIb}} \beta_{3}$ to achieve surface coverage with stationary platelets [22-24]. It has been proposed that the interaction between immobilized VWF and GPIb $\alpha$, generates an intracellular second messenger that signals the conversion of $\alpha_{\text {IIb }} \beta_{3}$ from a low affinity to a high affinity receptor for immobilized VWF $[25,26]$.

Analysis of the changes in $\left[\mathrm{Ca}^{2+}\right]_{\mathrm{i}}$ of the stationary platelets revealed that virtually all platelets exhibited low, non-oscillating $\left[\mathrm{Ca}^{2+}\right]_{\mathrm{i}}$ of around $50 \mathrm{nmol} \mathrm{L}^{-1}$. However, the platelets might have exhibited transient increase in $\left[\mathrm{Ca}^{2+}\right]_{i}$ immediately after platelet interaction with fibrin-bound VWF, as have been described by Nesbitt et al. [26] for interaction between immobilized VWF and platelets. Accordingly, under these experimental conditions, platelet binding via activated integrin $\alpha_{\text {IIb }} \beta_{3}$ is not associated with at least a persistent rise in $\left[\mathrm{Ca}^{2+}\right]_{i}$. Similar observations have earlier been made with platelets adhering to fibrinogen [18] or monomeric fibrin [27]. The observation that only $2 \pm 2 \%$ (mean $\pm \mathrm{SD} ; n=20$ ) of the adherent platelets bound annexin $\mathrm{V}$ is in accordance with the notion that, regardless of the agonist, a high elevation in $\left[\mathrm{Ca}^{2+}\right]_{\mathrm{i}}\left(\mu \mathrm{mol} \mathrm{L}{ }^{-1}\right.$ range) persisting during a certain time (minute range) is required for evoking membrane PS exposure [18,28].

When a thrombin solution $\left(100 \mathrm{nmol} \mathrm{L}^{-1}\right)$ was passed over fibrin-adherent platelets, $\left[\mathrm{Ca}^{2+}\right]_{\mathrm{i}}$ transiently increased from $50 \mathrm{nmol} \mathrm{L}^{-1}$ to a peak values of $1.1 \pm 0.2 \mu \mathrm{mol} \mathrm{L}^{-1}$ (mean \pm $\mathrm{SD}, n=5$ ) (Fig. 2a,b). The rapid increase in $\left[\mathrm{Ca}^{2+}\right]_{\mathrm{i}}$ was accompanied with a slow increase in the number of platelets 
(a)

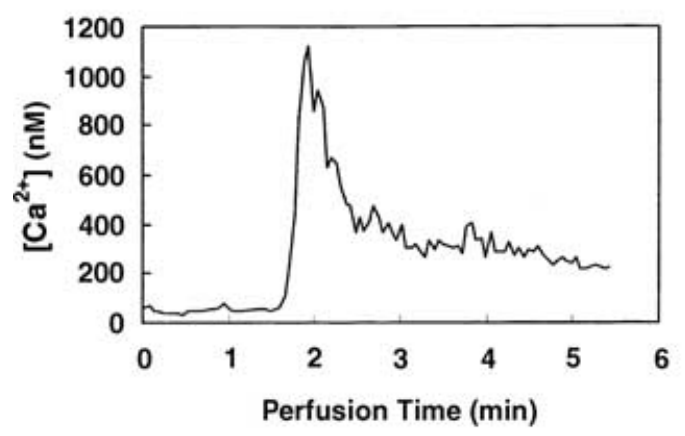

(c)

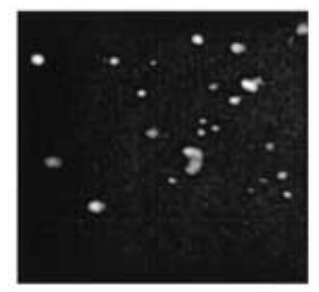

$2 \mathrm{~min}$

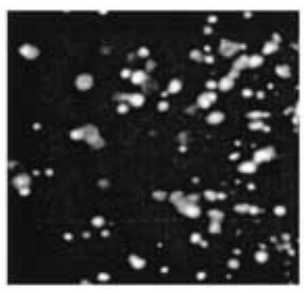

$10 \mathrm{~min}$ (b)

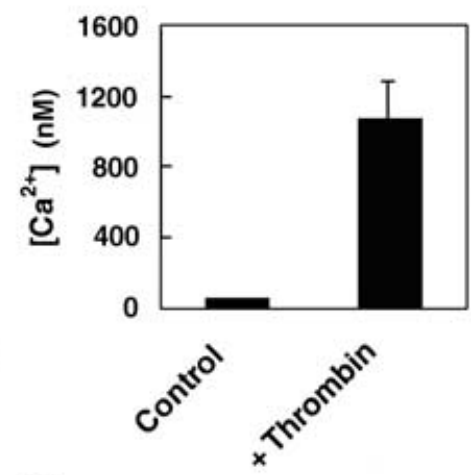

(d)

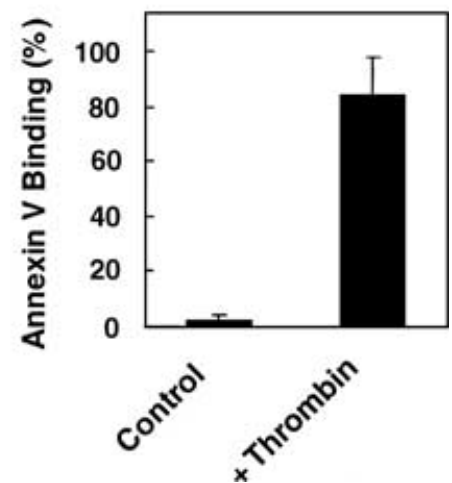

Fig. 2. Thrombin-induced calcium response and exposure of anionic phospholipids. Fura- 2 loaded platelets $\left(3.0 \times 10^{8}\right.$ cells $\left.\mathrm{mL}^{-1}\right)$ resuspended in Hepes buffer (see Fig. 1) were perfused at a wall shear rate of $1000 \mathrm{~s}^{-1}$ over a fibrin layer. After $10 \mathrm{~min}$, nonadherent platelets were removed by a perfusion with Hepes buffer. The fibrin layer with adherent platelets was then perfused with $100 \mathrm{nmol} \mathrm{L}^{-1}$ thrombin in Hepes buffer, and fura-2 fluorescence ratio images were captured every $10 \mathrm{~s}$. (a) Changes in $\left[\mathrm{Ca}^{2+}\right]_{\mathrm{i}}$ of 5 single platelets were averaged and plotted against the perfusion time. (b) Average $\left[\mathrm{Ca}^{2+}\right]_{\mathrm{i}}$ of fibrin-adherent platelets before perfusion with thrombin (control) and average peak values of $\left[\mathrm{Ca}^{2+}\right]_{\mathrm{i}}$ during perfusion with thrombin $(+$ thrombin) were calculated from the data used to construct Fig. 2(a). (c) In a separate experiment fibrin-adherent platelets were perfused with Hepes buffer containing thrombin $\left(100 \mathrm{nmol} \mathrm{L}^{-1}\right)$ and OG-labeled annexin $\mathrm{V}(1 \mu \mathrm{g} / \mathrm{mL})$. Fluorescence images were captured at regular time intervals. Typical fluorescence images taken 2 and $10 \mathrm{~min}$ after the start of the thrombin/annexin V perfusion are shown. (d) Percentage surface coverage with annexin $\mathrm{V}$ binding platelets prior to thrombin (Control) and $10 \mathrm{~min}$ after the start with the thrombin/annexin $\mathrm{V}$ solution ( + thrombin).

that bound annexin V (Fig. 2c). It could be argued that transport limitations are causing the relatively slow binding of annexin $\mathrm{V}$. Control experiments, however, showed that fibrin-adherent platelets that were pretreated with a calcium ionophore $\left(5 \mu \mathrm{mol} \mathrm{L}{ }^{-1}\right.$ ionomycin in the presence of $\left.3 \mathrm{mmol} \mathrm{L}^{-1} \mathrm{CaCl}_{2}\right)$ rapidly bound annexin $\mathrm{V}$ when perfused under the same conditions (data not shown).

Off-line analysis of the fluorescence images of randomly chosen microscopic fields, taken $10 \mathrm{~min}$ after the influx of thrombin and OG-labeled annexin V, revealed that $85 \pm 14 \%$ (mean $\pm \mathrm{SD} ; n=30$ ) of the surface was covered with annexin $\mathrm{V}$ binding platelets (Fig. 2d). By varying the thrombin concentration it appeared that $5 \mathrm{nmol} \mathrm{L}^{-1}$ of thrombin was sufficient to induce within $10 \mathrm{~min}$ the appearance of annexin $\mathrm{V}$ binding sites on 50\% of the adherent platelets (data not shown). This finding sharply contrasts from the situation where thrombin is added to platelets on fibrin(ogen) in the absence of flow and VWF. Thrombin causes under these conditions a repetitive spiking instead of a continuous elevation in $\left[\mathrm{Ca}^{2+}\right]_{i}[29]$ that is not followed by significant exposure of annexin $\mathrm{V}$ binding sites [30].
To explore whether the thrombin receptors PAR1 and/or GPIb are involved in the thrombin-induced responses of fibrinadherent platelets, experiments were performed in which fibrin-adherent platelets were incubated with the PAR1 ligand SFLLRN $\left(150 \mu \mathrm{mol} \mathrm{L}^{-1}\right)$. Like thrombin, SFLLRN caused a rapid and transient increase in $\left[\mathrm{Ca}^{2+}\right]_{i}$ with a peak value of about $0.25 \mu \mathrm{mol} \mathrm{L}^{-1}$. This response was lower than the response seen with thrombin. In contrast to the observation with thrombin, no increase in the number of annexin $\mathrm{V}$ binding platelets was observed. That is, surface coverage with annexin $\mathrm{V}$ binding platelets prior to and after treatment with SFLLRN was $2 \pm 1 \%$ (mean $\pm \mathrm{SD}, n=5$ ) and $2 \pm 2 \%$ (mean $\pm \mathrm{SD}, n=5$ ), respectively. It is apparent that in this flow system PAR1-signaling alone is unable to translocate sufficient PS from the inner leaflet to the outer leaflet of the platelet plasma membrane to bind annexin V. This could support the previous observation that in thrombin-induced platelet activation a cooperative role of PAR1 and GPIb is involved [31]. When the SFLLRN-treated platelets were subsequently exposed to thrombin $\left(100 \mathrm{nmol} \mathrm{L}^{-1}\right)$, a slight increase $(10 \%)$ in surface coverage with annexin $\mathrm{V}$ binding platelets was found. This finding is compatible with the notion 
that SFLLRN desensitizes the thrombin-induced procoagulant response of platelets [11].

Taken together, these results confirm that under conditions of high shear stress, attachment of stationary platelets on fibrin requires GPIb-VWF interaction to initiate a firm interaction between integrin $\alpha_{\mathrm{IIb}} \beta_{3}$ and VWF or fibrin. These GPIb- and integrin $\alpha_{\text {IIb }} \beta_{3}$-mediated interactions do not result in a substantial increase in $\left[\mathrm{Ca}^{2+}\right]_{\mathrm{i}}$, nor in exposure of PS in the outer leaflet of the plasma membrane. Furthermore, under these shear conditions, additional activation by thrombin is required to increase the cytosolic calcium concentration to levels that are sufficiently high to trigger PS exposure. The PAR1 agonist, SFLLRN, when compared with thrombin, fails to induce PS exposure under the present flow conditions.

\section{Platelet adhesion at low shear rate and exposure of anionic phospholipids}

To find support for the notion that the shear dependent VWFplatelet interaction, contributes to the thrombin-induced platelet procoagulant response, similar perfusion experiments were performed under conditions of low shear stress. In agreement with earlier published data [32], nonactivated platelets do not adhere on fibrin. After $10 \mathrm{~min}$ perfusion at a shear rate of $50 \mathrm{~s}^{-1}$, the area coverage with stationary platelets was less than $1 \%$.
In contrast, the number of stationary platelets greatly increased in time when the platelets were activated with thrombin $\left(100 \mathrm{nmol} \mathrm{L}^{-1}\right)$ just before they entered the flow chamber (Fig. 3a). After 10 min perfusion, $12 \pm 7 \%$ (mean \pm SD; $n=$ 15) of the total area was covered with adherent platelets (Fig. 3b). In comparison with high shear condition, the rate at which thrombin-activated platelets adhered to fibrin at low shear stress was much slower. We note that this is likely due to the lower transport rate of platelets to the adhesive surface. Phase contrast microscopy (Fig. 3c) showed that in addition to single adherent platelets also small aggregates (5-20 platelets) attached to the fibrin surface. Aggregation in the thrombinactivated platelet suspension was however, not observed. Cytosolic calcium concentrations were measured in adherent platelets 10 min after the start of the perfusion. The $\left[\mathrm{Ca}^{2+}\right]_{i}$ of these thrombin-activated platelets was $0.2 \pm 0.1 \mu \mathrm{mol} \mathrm{L}^{-1}$ (mean \pm $\mathrm{SD} ; n=5$ ) and thus higher than the basal level of $50 \mathrm{nmol} \mathrm{L}^{-1}$ of platelets that adhered to VWF in the absence of thrombin under high-shear conditions. Yet, after low-shear perfusion only a few platelets ( $11 \pm 8 \%$; mean $\pm \mathrm{SD}, n=30)$ bound annexin $\mathrm{V}$.

To investigate whether at low shear rate VWF was also involved in fibrin adhesion of thrombin-activated platelets, we investigated the effect of a blocking polyclonal rabbit antihuman VWF antibody $\left(10 \mu \mathrm{g} \mathrm{mL}^{-1}\right)$. With this antibody (a)

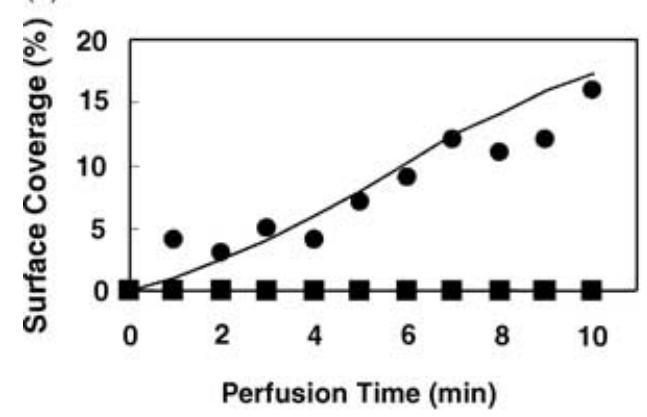

(c)

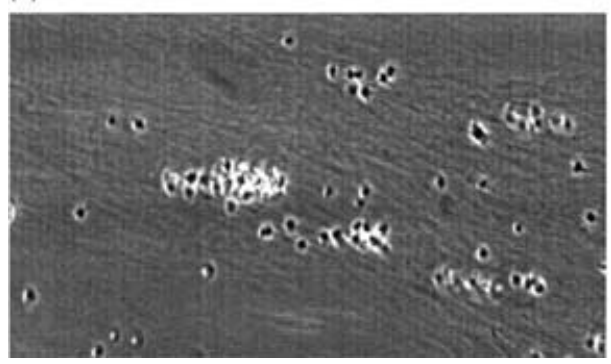

(b)

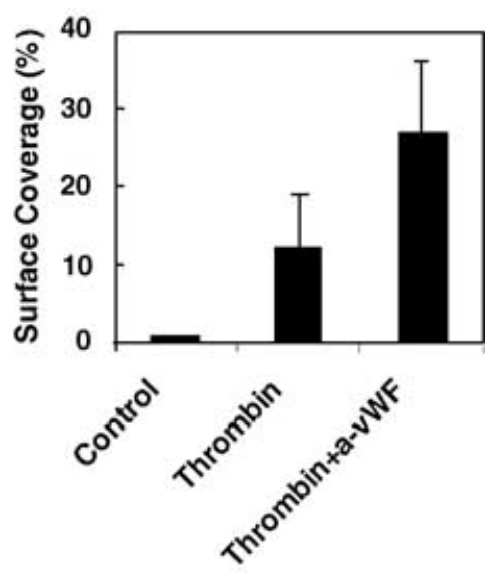

Fig. 3. Effect of thrombin on platelet adhesion to fibrin under low shear stress. (a) Calcein-loaded washed platelets $\left(3.9 \times 10^{8}\right.$ cells $\left.\mathrm{mL}^{-1}\right)$ resuspended in Hepes buffer (see Fig. 1) were perfused in the absence ( $)$ and presence of $100 \mathrm{nmol} \mathrm{L}^{-1}$ thrombin $(\bullet)$ at a wall shear rate of $50 \mathrm{~s}^{-1}$ over a fibrin layer that was treated with human VWF $\left(10 \mu \mathrm{g} \mathrm{mL}^{-1}\right)$ and PPACK $\left(50 \mu \mathrm{mol} \mathrm{L}^{-1}\right)$ as described. Fluorescence images were captured and analyzed off-line for the surface coverage with platelets. (b) Following a 5-min rinse with Hepes to remove non-bound platelets, fluorescence images were captured from 5 different microscopic fields and off-line analyzed for surface coverage with stationary platelets. VWF and PPACK treated fibrin were perfused with: non-treated, washed platelets (control) and thrombin-activated platelets (thrombin). In addition, thrombin-activated platelets were perfused over fibrin that was incubated with $10 \mu \mathrm{g} \mathrm{mL}^{-1}$ polyclonal antihuman VWF antibody (Thrombin $+\mathrm{a}-\mathrm{VWF}$ ). (c) Phase contrast image of the fibrin layer after 10 min perfusion with thrombin-activated platelets and subsequent rinse with Hepes. 
present, the area coverage with adherent platelets was $27 \pm 9 \%$ (mean $\pm \mathrm{SD} ; n=15$ ), which is not significantly different $(P=0.13)$ from that observed in the control experiment, i.e. $12 \pm 7 \%$ (mean $\pm \mathrm{SD} ; n=15$ ). Accordingly, at low shear rate, VWF does not appear to play a significant role in the adhesion of thrombin-activated platelets to fibrin.

\section{Botrocetin and exposure of PS at fibrin-adherent platelet}

To achieve VWF-mediated platelet adhesion at a low shear rate $\left(50 \mathrm{~s}^{-1}\right)$, washed platelets were passed over a VWF-fibrin layer that was preincubated with botrocetin $\left(5 \mathrm{U} \mathrm{mL}^{-1}\right)$. Ten minutes after the start of the flow $11 \pm 4 \%$ (mean $\pm \mathrm{SD} ; n=10$ ) of the area was covered with platelets. The cytosolic calcium concentration, amounting to $70 \mathrm{nmol} \mathrm{L}^{-1}$, of these platelets was not substantially increased above the basal level of $50 \mathrm{nmol} \mathrm{L}^{-1}$. The percentage of adherent platelets that bound annexin $\mathrm{V}$ also remained low, namely $1.3 \pm 2.3 \%$ (mean $\pm \mathrm{SD} ; n=20$ ).

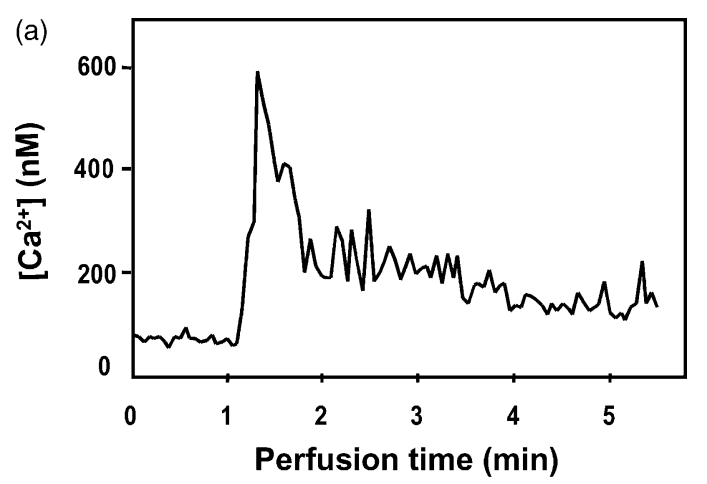

(b)

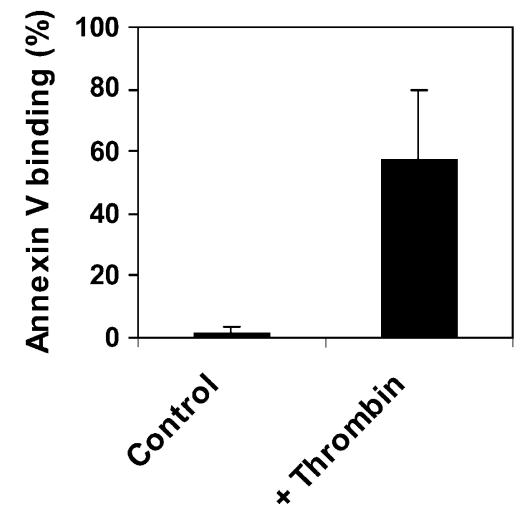

Fig. 4. Cytosolic calcium levels and annexin V binding of platelets that adhere botrocetin-mediated to fibrin at low shear. Fura-2-loaded platelets were perfused at a wall shear rate of $50 \mathrm{~s}^{-1}$ over fibrin that was incubated for $1 \mathrm{~h}$ with human VWF $\left(10 \mu \mathrm{g} \mathrm{mL}^{-1}\right)$, PPACK $\left(50 \mu \mathrm{mol} \mathrm{L}^{-1}\right)$ and botrocetin $\left(5 \mathrm{U} \mathrm{mL}^{-1}\right)$. Ten minutes after the start of the perfusion experiment, Hepes buffer containing $100 \mathrm{nmol} \mathrm{L}^{-1}$ thrombin was perfused and fura-2

fluorescence ratio images were captured every $10 \mathrm{~s}$. (a) Changes in $\left[\mathrm{Ca}^{2+}\right]_{\mathrm{i}}$ of five single platelets were averaged and plotted against the perfusion time. (b) Fibrin-adherent platelets (see panel a) were perfused with Hepes buffer containing $1 \mu \mathrm{g} \mathrm{mL}^{-1}$ OG-labeled annexin $\mathrm{V}$ (control) or with Hepes buffer containing $100 \mathrm{nmol} \mathrm{L}^{-1}$ thrombin and $1 \mu \mathrm{g} / \mathrm{mL}$ OG-labeled annexin $\mathrm{V}$ ( + thrombin). Fluorescence images of five different microscopic fields were captured after $10 \mathrm{~min}$ perfusion with platelets and $5 \mathrm{~min}$ perfusion with Hepes. The surface coverage with annexin $\mathrm{V}$ binding platelets was estimated as described under Material and methods.
However, when a thrombin solution $\left(100 \mathrm{nmol} \mathrm{L}^{-1}\right)$ was passed over the fibrin/botrocetin-adherent platelets, $\left[\mathrm{Ca}^{2+}\right]_{\mathrm{i}}$ immediately increased to $0.7 \mu \mathrm{mol} \mathrm{L}^{-1}$ (Fig. 4a), while $57 \pm 23 \%$ (mean $\pm \mathrm{SD} ; n=20$ ) of the adherent platelets bound annexin $\mathrm{V}$, as measured $10 \mathrm{~min}$ after the start of the perfusion with a thrombin-annexin V solution (Fig. 4b). That under these conditions platelet adhesion was mediated by VWF appeared from the observation that preincubation of the botrocetin-contained coverslip with anti-VWF antibody completely abolished botrocetin-induced platelet adhesion.

In conclusion, this study that utilized a plasma-free flow system clearly demonstrated that shear-induced platelet adhesion to fibrin is not accompanied with substantially elevated $\left[\mathrm{Ca}^{2+}\right]_{\mathrm{i}}$, nor associated with exposure of annexin $\mathrm{V}$ binding sites on the platelet surface. Thrombin, however, induced a transient increase in $\left[\mathrm{Ca}^{2+}\right]_{i}$ of the adherent platelets, which at high shear but not at low shear was followed by the exposure of annexin $\mathrm{V}$ binding sites. This indicates that VWF-mediated adhesion of platelets to fibrin is a prerequisite for thrombin to expose PS on the outer leaflet of the platelet plasma membrane. It is apparent that sufficiently high $\left[\mathrm{Ca}^{2+}\right]_{\mathrm{i}}$ levels for maximal PS exposure in fibrin-adherent platelets are obtained by a synergistic signal mechanism in which both VWF and thrombin need to interact with their receptors on fibrin-adherent platelets.

\section{Acknowledgements}

This work was supported by grants 902-26-192 and 902-68-241 from the Dutch Organization for Scientific Research (NWO) and grant 910-408-027 from ZonMw-NWO/INSERM.

\section{References}

1 Brown RS, Niewiarowski S, Stewart GJ, Millman M. A double-isotope study on incorporation of platelets and red cells into fibrin. J Lab Clin Med 1977; 90: 130-40.

2 Kumar R, Béguin S, Hemker HC. The effect of fibrin clots and clotbound thrombin on the development of platelet procoagulant activity. Thromb Haemost 1995; 74: 962-8.

3 Béguin S, Kumar R, Keularts IMLW, Seligsohn U, Coller BS, Hemker HC. Fibrin-dependent platelet procoagulant activity requires GPIb receptors and von Willebrand factor. Blood 1999; 93: 564-70.

4 Bevers EM, Comfurius P, van Rijn JL, Hemker HC, Zwaal RFA. Generation of prothrombin-converting activity and the exposure of phosphatidylserine at the outer surface of platelets. Eur J Biochem 1982; 122: 429-36.

5 Hantgan RR, Hindriks G, Taylor RG, Sixma JJ, de Groot PG. Glycoprotein Ib, von Willebrand factor, and glycoprotein IIb: IIIa are all involved in platelet adhesion to fibrin in flowing whole blood. Blood 1990; 76: 345-53.

6 Endenburg SC, Hantgan RR, Lindeboom Blokzij1 L, Lankhof H, Jerome WG, Lewis JC, Sixma JJ, de Groot PG. On the role of von Willebrand factor in promoting platelet adhesion to fibrin in flowing blood. Blood 1995; 86: 4158-65.

7 Savage B, Shattil SJ, Ruggeri ZM. Modulation of platelet function through adhesion receptors. A dual role for glycoprotein IIb-IIIa (integrin $\alpha_{\mathrm{IIb}} \beta_{3}$ ) mediated by fibrinogen and glycoprotein Ib-von Willebrand factor. J Biol Chem 1992; 267: 11300-6.

8 Zaffran Y, Meyer SC, Negrescu E, Reddy KB, Fox JEB. Signaling across the platelet adhesion receptor glycoprotein Ib-IX induces $\alpha_{\text {IIb }} \beta_{3}$ 
activation both in platelets and a transfected Chinese hamster ovary cell system. J Biol Chem 2000; 275: 16779-87.

9 Jen CJ, Lin JS. Direct observation of platelet adhesion to fibrinogen- and fibrin-coated surfaces. Am J Physiol 1991; 261: H1457-63.

10 Savage B, Ruggeri ZM. Selective recognition of adhesive sites in surface-bound fibrinogen by glycoprotein IIb-IIIa on nonactivated platelets. J Biol Chem 1991; 266: 11227-33.

11 Dörmann D, Clemetson KJ, Kehrel BE. The GPIb thrombin-binding site is essential for thrombin-induced platelet procoagulant activity. Blood 2000; 96: 2469-78.

12 Andersen H, Greenberg DL, Fujikawa K, Xu WF, Chung DW, Davie EW. Protease-activated receptor 1 is the primary mediator of thrombinstimulated platelet procoagulant activity. Proc Natl Acad Sci USA 1999; 96: 11189-93.

13 Salemink I, Franssen J, Willems GM, Hemker HC, Lindhout T. Inhibition of tissue factor-factor VIIa-catalyzed factor X activation by factor Xatissue factor pathway inhibitor. A rotating disc study on the effect of phospholipid membrane composition. J Biol Chem 1999; 274: 28225-32.

14 Schoen P, Lindhout T, Franssen J, Hemker HC. Low molecular weight heparin-catalyzed inactivation of factor Xa and thrombin by antithrombin III, effect of platelet factor 4. Thromb Haemost 1991; 66: 435-41.

15 Cauwenberghs N, Meiring M, Vauterin S, van Wyk V, Lamprecht S, Roodt JP, Novak L, Harsfalvi J, Deckmyn H, Kotze HF. Antithrombotic effect of platelet glycoprotein Ib-blocking monoclonal antibody Fab fragments in nonhuman primates. Arterioscler Thromb Vasc Biol 2000; 20: $1347-53$.

16 Depraetere H, Ajzenberg N, Girma JP, Lacombe C, Meyer D, Deckmyn $\mathrm{H}$, Baruch D. Platelet aggregation induced by a monoclonal antibody to the A1 domain of von Willebrand factor. Blood 1998; 91: 3792-9.

17 Coller BS, Anderson KM, Weisman HF. The anti-GPIIb-IIIa agents: fundamental and clinical aspects. Haemostasis 1996; 26: 285-93.

18 Heemskerk JWM, Vuist WMJ, Feijge MAH, Reutelingsperger CPM, Lindhout T. Collagen but not fibrinogen surfaces induce bleb formation, exposure of phosphatidylserine, and procoagulant activity of adherent platelets: Evidence for regulation by protein tyrosine kinase dependent $\mathrm{Ca}^{2+}$ responses. Blood 1997; 90: 2615-25.

19 Remijn JA, Sixma JJ, de Groot PG. Fibrin formation under conditions of flow results in fibrin fibers carried along by flow and deposited downstream to preabsorbed fibrinogen [abstract]. Thromb Haemost 1999; (Suppl.): 41.

20 Billy D, Briedé JJ, Heemskerk JWM, Hemker HC, Lindhout T. Prothrombin conversion under flow conditions by prothrombinase assembled on adherent platelets. Blood Coagul Fibrinolysis 1997; 8: $168-74$.
21 Grynkiewicz G, Poenie M, Tsien RY. A new generation of $\mathrm{Ca}^{2+}$ indicators with greatly improved fluorescence properties. $J$ Biol Chem 1985; 260: 3440-50.

22 Ruggeri ZM, De Marco L, Gatti L, Bader R, Montgomery RR. Platelets have more than one binding site for von Willebrand factor. J Clin Invest 1983; 72: 1-12.

23 Savage B, Saldivar E, Ruggeri ZM. Initiation of platelet adhesion by arrest onto fibrinogen or translocation on von Willebrand factor. Cell 1996; 84: 289-97.

24 Yap L, Hughan SC, Cranmer SL, Nesbitt WS, Rooney MM, Giuliano S, Kulkarni S, Dopheide SM, Yuan Y, Salem HH, Jackson SP. Synergistic adhesive interactions and signaling mechanisms operating between platelet glycoprotein $\mathrm{Ib} / \mathrm{IX}$ and integrin $\alpha_{\mathrm{IIb}} \beta_{3}$. Studies in human platelets and transfected Chinese hamster ovary cells. J Biol Chem 2000; 275: 41377-88.

25 De Marco L, Girolami A, Russell S, Ruggeri ZM. Interaction of asialo von Willebrand factor with glycoprotein $\mathrm{Ib}$ induces fibrinogen binding to the glycoprotein IIb/IIIa complex and mediates platelet aggregation. $J$ Clin Invest 1985; 75: 1198-203.

26 Nesbitt WS, Kulkarni S, Giuliano S, Goncalves I, Dopheide SM, Yap CL, Harper IS, Salem HH, Jackson SP. Distinct glycoprotein $\mathrm{Ib} / \mathrm{V} / \mathrm{IX}$ and integrin $\alpha_{\mathrm{II}} \beta_{3}$-dependent calcium signals cooperatively regulate platelet adhesion under flow. J Biol Chem 2002; 277: 2965-72.

27 Sanders MW, Nieuwenhuys CMA, Feijge MAH, Rook M, Béguin S, Heemskerk JWM. The procoagulant effect of thrombin on fibrin(ogen)bound platelets. Haemostasis 1998; 28: 289-30.

28 Pasquet JM, Dachary-Prigent J, Nurden AT. Calcium influx is a determining factor of calpain activation and microparticle formation in platelets. Eur J Biochem 1996; 239: 647-54.

29 Heemskerk JWM, Feijge MAH, Henneman L, Rosing J, Hemker HC. The $\mathrm{Ca}^{2+}$-mobilizing potency of alpha-thrombin and thrombin-receptor-activating peptide on human platelets. Concentration and time effects of thrombin-induced $\mathrm{Ca}^{2+}$ signaling. Eur J Biochem 1997; 249: $547-55$.

30 Goodwin CA, Wheeler-Jones CPD, Kakkar VV, Deadman JJ, Authi KS, Scully MF. Thrombin receptor activating peptide does not stimulate platelet procoagulant activity. Biochem Biophys Res Commun 1994; 202: $321-7$.

31 De Candia E, Hall SW, Rutella S, Landolfi R, Andrews RK, De Cristofaro R. Binding of thrombin to glycoprotein Ib accelerates the hydrolysis of PAR-1 on intact plateles. J Biol Chem 2001; 276: 4692-8.

32 Hantgan RR, Taylor RG, Lewis JC. Platelets interact with fibrin only after activation. Blood 1985; 65: 1299-311. 